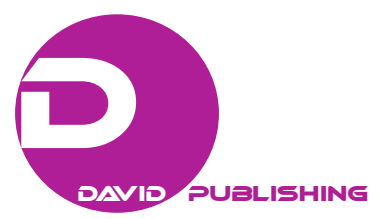

\title{
China’s English Newspaper Reading Teaching Research Under Research-Oriented Teaching Mode*
}

\author{
LUO Rui-feng \\ Sichuan Vocational and Technical College, Suining City, Sichuan,China \\ Shanghai International Studies University, Shanghai, China
}

\begin{abstract}
In recent 10 years, teaching English newspaper reading for English majors in China has got rapid development. At the same time, social demand for college students' English newspaper reading ability has also improved. But the existing teaching effect of English newspaper reading course is not ideal. What is proposed in this paper is to apply the research-oriented teaching mode to the teaching of English newspaper reading and expound the three stages of pre-reading, reading, and after-reading respectively in order to subvert the teaching of reading class over which teachers dominate traditionally, to change the center of the double main bodies , to develop learners' intellectual and non-intellectual factors of comprehensive quality, and to improve their ability of discovering, researching, and solving the problems.
\end{abstract}

Keywords: English newspaper reading teaching, research-oriented teaching mode, pre-reading, reading, after-reading

\section{Introduction}

In the era of information explosion of big data, with a strong information consciousness and retrieving information resources, analysis and evaluation information, effective use of information talent is urgently needed by society. In order to improve the learners' ability to use information retrieval and analysis, in the early 1930s, American primary and secondary schools had carried out the NIE (Newspaper In Education) program, which applied print resources to teaching and made it become a kind of beneficial complements of classroom lectures. According to the newspaper association statistics, so far more than 60 countries have developed NIE education research projects, of which more than 20 countries have included newspapers and education in the law or have taken newspapers and periodicals teaching in formal classroom of students. In China, more than $80 \%$ of colleges and universities opened English newspaper reading class (DU, 2012). Various kinds of newspaper reading materials (ZHOU, 1994; DUANMU, 1994) have been published one after another and National Newspaper Reading Teaching Meeting has been held regularly.

\footnotetext{
* Acknowledgements: (1) The Application of Dynamic System Theory in English and Chinese Attrition by General Project of Humanities and Social Science of Education Department of Sichuan Province (Project Number: 16SB0293); (2) The Effect of Early Childhood Translation under the Theory of Dynamic System on Promotion of Children's Bilingual Education by General Project of Humanities and Social Science of Education Department of Sichuan Province (Project Number: 15SB0255).

LUO Rui-feng, Lecturer, Foreign Languages Department, Sichuan Vocational and Technical College; Ph.D., School of English Studies, Shanghai International Studies University.
} 
In 2007, Ministry of Education of China promulgated college English curriculum requirements which put forward three levels of requirements on college students' English reading ability: Firstly, the students can read specialized English teaching materials with the help of a dictionary, familiarize the theme, master the center of the effect, and understand the main facts and details about English newspaper articles. Secondly, the students can understand the general theme of the mass of newspapers and magazines in English countries. Thirdly, the students can read English newspapers and magazine articles abroad. In addition, the College English Test Band 4 and Band 6 of China will also be an important criterion for students' reading and comprehension of British and American newspapers and periodicals. In recent 10 years, English newspaper reading teaching has been rapidly developed. At the same time, social demand for college students' English newspaper reading ability has also improved.

\section{The Current Situation of English Newspaper Reading Teaching}

At home and abroad, the application of English Newspaper reading in English teaching is very common, and America's international NIE program is the most influential one. More than $80 \%$ of the universities of China offer newspaper reading courses (DU, 2012). Contents of newspapers and magazines keep pace with times, contain the latest developments in political, economic and cultural development all over the world, and set up a platform for the understanding of British and American cultures for learners, at which a single language ability of ascension is unable to achieve.

Although a lot of newspaper reading materials, such as British and American Newspaper Reading Course, American and British Newspapers and Anthologies, and English newspapers and magazines, such as English Tutoring Newspaper, Learn English Newspaper have been already published in China, in most existing English newspaper reading courses, teachers still adopt the traditional mode which is dominated by teachers and in which teaching language knowledge is still the core. Each word and grammar in articles are explained so carefully that English newspaper reading classes have become English intensive reading class, ignoring the cultivation of the ability to scan. But newspaper article itself is different from other types of articles and involves the newspapers terms which are combination of journalism, lexicology, rhetoric, stylistics, and sociology (LIU, 2000). In addition , the newspaper terms also include various aspects of the title of news, syntax, rhetoric and culture, etc.

In 2009, the 7th National Conference on College English Newspapers and Periodicals teaching directly pointed out that English newspapers and periodicals class is valuable to cultivate high quality talents in new era and newspapers and periodicals teaching materials must be competency-based teaching materials. If it is exercised properly, the students can not only master the modern English, broaden the knowledge, but also cultivate the students' thinking ability, analysis ability, comprehensive induction ability, and innovation ability (XU, 2009). In addition, many newspapers and magazines, such as English Tutoring Newspaper and English Newspaper, can set up editorial contents which conform to all ages from the primary schools to universities. In this way, different degrees of knowledge can meet the different demands of students. In a word, English newspaper reading teaching is good.

However, the existing English newspaper reading teaching still exists some shortcomings. Newspaper reading is a kind of special reading training, and has its own training emphasis and difficulties. Newspapers and its terms are combination of journalism, lexicology, rhetoric, stylistics, and sociology (LIU, 2000), so the press is 
also known as an enormous factory of using new words and coined words (DUANMU, 1994). In addition, the title of the newspaper reading also includes news, syntactic and rhetorical features, and news headlines are often seeking short refining and using omitting words means. Front-facing attributive and the noun attributive are commonly used in refining sentence patterns and rhetoric metonymy, metaphor and idioms are often used to expand expression effect. But many teachers still teach English newspaper reading class like intensive reading and extensive reading class. Some teachers use the traditional mode in order to teach language knowledge as the core and explain each word and grammar carefully; some teachers put more emphasis on expanding cultural background knowledge and learners' vocabulary, but ignore the fast reading skills training. When teaching, the contents of the newspaper reading classes are often not systematic enough, and relatively single evaluation after class is often used. Hence, the traditional mode of English newspaper reading course can not achieve ideal effect. In newspaper reading courses, teachers, obsessed with supplement of newspaper articles, cultural knowledge and enlargement of vocabulary, always make the classes become extensive reading classes. It can be said that inefficiency of teaching content system, lack of teaching interaction, relatively single assessment, and the inadequate and unsatisfactory teaching effect have become widely accepted defects of English newspaper reading courses.

\section{English Newspaper Reading Teaching Under the Research-Oriented Teaching Mode}

\section{The Definition of Research-Oriented Teaching Mode}

The research-oriented teaching mode (also called the teaching mode with discussion), based on humanistic psychology and cognitive structure learning, refers to that the teachers, on the basis of the course content and students' knowledge accumulation, guide students to creatively use knowledge and ability to find, research, solve the problem, and cultivate ability and thinking of the new teaching mode in discussion of the accumulation of knowledge (WEI, 2002).

The research-oriented teaching mode is different from predominant one-way knowledge teaching mode with exploring, practicality, initiative, and comprehensive characteristics. It pays much concern on learners' autonomous learning, emphasizes the learners in practice to use a variety of knowledge discovery and problem solving skills, and pays much attention to the learning process, to make learners learn study and research methods. Research-oriented teaching mode often takes discussion method, case analysis, the task-based teaching method, social investigation, writing method as the main teaching approaches. It embodies the modern quality education and innovation education so it is open and flexible.

\section{The Advantages of the Combination of Research-Oriented Teaching With English Newspaper Reading Teaching and Its Running Mechanism}

The four advantages. Compared with other traditional teaching modes such as one-way lectures, research-oriented teaching mode has four advantages (WEI, 2002).

First of all, on the teaching target, the research-oriented teaching mode transfers oneness to diversity that teachers attach equal importance to learning methods and knowledge itself, and intends to improve the learners' listening, speaking, reading, writing and self-learning ability, analytical ability, research ability, the emotion, motivation, faith and the ability of comprehensive demand accordingly. This shift happens to have the same view with the whole-person development of the postmodern education, thinking that education should bring up a batch 
of citizens with critical ability which can challenge the cultural dominance of citizenship through the understanding of the multicultural cross cultural marginal (HU, 2007). And therefore, the purpose of English newspaper reading teaching is to cultivate innovative foreign language talents. So this shift is necessary. Second, in the teaching subject, teaching mode is realized from longitudinal relationship to horizontal relations between teachers and students. On the contrary to the traditional pattern of teacher leading democracy and equality, the teachers in this method in the classroom serve as guides and learning partners to the learners and as the main bodies in the teaching process while learners play central roles in the learning process. This shift is consistent with the introspection of English newspaper reading teaching theory. Introspection theory demands learners playing active roles in the study of the subject, gives learners more self-learning, thinking and opportunities to practice, and makes them really understand and introspect their own English reading ability, while teachers play the roles of introspection of enlightening and guiding them (YANG \& HU, 2012). There is no doubt that the switch to the improvement of English newspaper reading teaching is very important. Third, from the view of learners' learning, research-oriented teaching mode is implemented not by cramming but by happy learning transformation. In the research-oriented teaching mode, the non-intelligence factors, such as the learner's emotion, attitude and faith, are fully appreciated by teaching and learners can acquire the power of partnerships and the joy of success from the fun of learning. Fourth, the research-oriented teaching mode is previewed from theory to practice from the transformation to the society. Learners find that the improved ability to solve the problem and research can provide them valuable basis and experiences in the future work.

Research-oriented teaching mode of English newspaper reading course puts emphasis on providing background information, teachers' interpretation of English newspaper reading skills, teachers' major statue in the teaching process while students' major statue in the learning process, reading supplement of similar materials after class and the dynamic and open comments on students.

The running mechanism. Application of the research-oriented teaching mode in the teaching of English newspaper reading can overturn the traditional mode which teachers dominate teaching in class, change the center of the double major statue, develop learners' intellectual and non-intellectual factors of comprehensive quality, and improve their discovery, research, and the ability to solve the problem. So, in this paper, the three stages of pre-reading, reading, after-reading will be explained as follows.

In the beginning stage of reading, the background information of the materials is vitally important. So, before the formal English newspaper reading teaching, the 2-3 minutes warming up of the culture is very necessary. But not all articles will be to provide the background information of teachers and activation of leading is more effective than by leading (SHENG, ZHAO, \& ZHANG, 2006). The background of cultural information combined with learners' knowledge of the article, has been shown to activate learners, to make learners understand further and to make learning more effective. Therefore, Chinese newspaper reading cannot be struck down, but should be encouraged to promote, because Chinese newspaper reading will help learners to effectively create different cultural background information, which is good for English newspaper reading. In addition to this, after class, teachers should also encourage learners to read more materials related to similar topics of the article, in addition to the background of cultural information.

In reading, teachers are main bodies in the teaching process, and learners are main bodies in the learning process, so the teachers should no longer be the dominant of class, and should fully arouse the learners to 
participate in teaching, stimulate interest in reading. Research method, discussion method, case analysis, the task-based teaching method, social investigation, and writing method should be as the main teaching approaches. But at the same time, the teacher is also essential for the interpretation of English newspaper reading skills, which contains the recognition and reasoning, writing style and intentions, etc. Only understanding the meaning of the paper is far from enough and the learners should understand more contents, discourse structure, and even the author's intention, and do the further evaluation and application (HE, 2012).

With the improvement of information technology which started in the mid 1960s, foreign language teaching by network undergo rapid development. With the Internet, newspaper reading teaching content is more effective and the teaching process becomes more diversified and interactive and teaching feedback is more dynamic and timely. In the reading and after-reading phases, learners have formed strong self-control and initiative ability that teachers can use internet to communicate and give non-paper assignments and exams, such as schedule, but the teaching plan and teaching material based on the target should also be finished.

In the after-reading phase, in addition to the extracurricular supplementary reading materials, teachers should set up a set of dynamic and open process evaluation for learners and pay attention to the process that learners form the ability of analysis, problem solving and exploring truth activities (WANG, 2011). Research-oriented teaching mode emphasizes the learners' intellectual and non-intellectual factors of comprehensive qualities and aims to improve their discovery, research and problem solving skills. So English newspaper reading teaching should be a comprehensive consideration which is open and dynamic.

\section{Conclusion}

Different from predominantly one-way knowledge teaching mode, the most outstanding feature of research-oriented teaching mode combining English newspaper reading teaching is to form learners' autonomous learning. The newly method emphasizes the ability of learners to use a variety of knowledge to discover and solve the problems in practice and pays attention to the learning process, through which learners can learn to study and acquire research methods. This paper expounds the three stages of the pre-reading, reading, and after-reading of research-oriented teaching mode combining with English newspaper reading, and eventually helps developing learners' intellectual and non-intellectual factors of comprehensive quality, improving their discovery, research, and forming the ability to solve the problems. Of course, the new teaching mode this paper put forward is not perfect enough and is lack of sufficient practical verification.

\section{References}

DU, H. L. (2012). The application and practice of double-subject interactive teaching mode in the newspapers English teaching. Journal of Qiqihar Junior Teachers' College, 4, 143-145.

DUANMU, Y. W. (1994). Reading course in American \& British news publications. Nanjing: Nanjing University Press.

HE, F. L. (2012). Multidimensional view of English newspaper reading model. The China Newspaper Industry, 7, $239-240$.

HU, Y. F. (2007). On the enlightment of post-modern education theory on the revolution of Chinese primary and middle school education. Journal of Helongjiang College of Education, 3, 29-31.

LI, J. P., \& LU, X. F. (2004). Thinking about carrying out the research-based study in colleges and universities. Heilongjiang Researches on Higher Education, 12, 86-87.

LIU, Y. H. (2000). The characteristics and the teaching design of English newspaper reading course. Journal of Xi'an Foreign Languages University, 4, 89-92. 
SHENG, A. F., ZHAO, Y. R., \& ZHANG, L. (2006). The schema-construction strategy in English newspapers course. Journal of Xi'an International Studies University, 6, 46-48.

The Ministry of Education. (2007). College English curriculum requirements. Beijing: Higher Education Press.

WANG, M. (2011). The network English reading model based on the theory of dynamic systematic theory. Foreign Language World, 2, 43-64.

WEI, B. P. (2002). Innovation education and the teaching model reform—On research-oriented teaching. China Adult Education, $11,48-49$.

XU, X. H. (2009). The seventh session of the national conference on college English newspapers and periodicals teaching. Foreign Languages Research, 6, 16.

YANG, Y., \& HU, Y. (2012). English newspaper reading teaching based on the theory of the introspection. China Newspaper Industry, 5, 151-152.

ZHOU, X. L. (1994). Selected articles from American \& British newspapers \& anthologies. Beijing: Peking University Press. 